\title{
Nano-materials for Gene Therapy: An Efficient Way in Overcoming Challenges of Gene Delivery
}

Salam Massadeh ${ }^{1 *}$, Manal Al-Aamery', Shahad Bawazeer ${ }^{1}$, Othman AIAhmad ${ }^{1}$, Rawan AISubai', Suzan Barker ${ }^{2}$ and Duncan Craig $^{2}$

${ }^{1}$ King Abdulla International Medical Research Center, King Saud Bin Abdulaziz University for Health Sciences, Developmental Medicine Department, King Abdul Aziz Medical City, Ministry of National Guard health Affairs, Riyadh, KSA, Saudi Arabia

${ }^{2}$ University College London, School of Pharmacy, 29-39 Brunswick Square, London WC1N 1AX, UK

\begin{abstract}
RNA interference (RNAi) is one of the most exciting and revolutionary new approaches to therapies that have attracted considerable amount of attention within the last few decades. Interfering RNAs (iRNA) are a major biological macromolecules that regulate specific gene sequencing, silencing and down regulating. Non coding RNA may lead to the development of a new range of potentially thousands of therapeutics. If efficiently used, iRNA is considered as a potent therapeutic agent for different disease types including viral diseases and cancer. However, the major obstacle that stands in the way of realization of such therapies is the in vivo delivery of RNAi fragments, like small interfering RNAs (siRNAs). The optimal approach to deliver si RNAs would be one to guarantee targeted delivery and high stability, a method that can protect the delivered material from undesirable immune response. In this review, we will shed the light on the use of biocompatible nanoparticles as safe delivery vehicles of genetic material.
\end{abstract}

Keywords: Nano genetics; Gene therapy; siRNA; mRNA; Nonviral delivery; Liposomes; Polymer nanoparticles; Dendrimers; Gold nanoparticles; Magnetic nanoparticles; Quantum dots

\section{Introduction}

Nanotechnology is a field that has been developed some decades ago, since then it has been expanding rapidly; and it has gained the attention of many scientists [1-5]. Nanotechnology applies synthetic chemistry to fabricate Nano scale building blocks, which could be functional on their own, with other materials Recently, novel devices have been fabricated and used from nanomaterial, e.g. new processors, fuel cells, energy storage devices in batteries, LEDs and photo electrochemical cells [6-10]. In addition, bio nanotechnology is a science that made use of biological building blocks to fabricate useful tools at the Nano scale [11-18]. Furthermore, the detection of biomolecules is of immense potential in the direction of molecular sensing in addition to self-assembly [19-21]. Furthermore, other sophisticated structures like animal viruses plus bacteriophages could be assembled at the Nano scale, such bio-nanostructures recognition can lead to the "bottom up" assembly. Furthermore, bio-nanotechnology is the application of biological building blocks intended for the improvement of novel technologies on the Nano scale. Besides, bionanotechnology is evidently not restricted to molecular functions; yet, they exhibit a broader capacity. Other functions of bio-nanotechnology include the applications of oligomers, peptide nanotubes, and metal nanowires. Indeed, bio nanotechnology is one of the key technologies of the $21^{\text {st }}$ century that merges material science and biotechnology; it is currently being studied and optimized. This field involves the utilization of biological systems such as cells, cellular components, and proteins, to manufacture efficient nanostructures. Nanotechnology is the new utensil that explores bimolecular structures, functions and properties. Bio nanotechnology made it possible to determine structural elements of cells, molecular recognition and drug delivery [11-13,22-42] (Table 1). In the same vein, gene therapy is a medical intervention that uses genes for the treatment or prevention of disease. If the gene of interest is delivered properly to the desired site, then this strategy would allow the direct insertion of a gene into a specific cell. Gene therapy has gained massive researchers' interest because of its potential to be an alternative for surgery and drug treatments. Gene therapy have been applied to replace a mutated gene that causes disease, knocking out mutated genes, and introducing new genes into cells to help fight a disease [24,43,44]. Even though gene therapy could be a promising treatment option for a number of diseases, its safety is still negotiable. Therefore, different types of biocompatible nanoparticles have been used to deliver genes intended for gene therapy to overcome the disadvantages encountered with the traditional methods used for genetic material delivery. In this review we will shed the light on the types of nanoparticles that have been used to deliver genes intended for gene therapy [45-48]. Moreover, RNA interference (RNAi) is one of the most exciting and revolutionary new approaches to therapies that have attracted considerable amount of attention within the last few decades. It has been found that gene expression may be controlled at the level of messenger RNA via noncoding RNAs. RNAi is an important pathway that leads to explicit gene silencing and down regulating. Non coding RNA may lead to the development of a new range of potentially thousands of therapeutics. If efficiently used, RNAi is considered as a potent therapeutic agent for different disease types including viral diseases and cancer. Plus, microRNA (miRNA) and small interfering RNA (siRNA) may be used as curative agents on their own, as they both adjust gene expression with high specificity [49-61]. A fare example of such an approach is in the treatment of cancer, whereby the siRNA may selectively increase the susceptibility of the cell to the low molecular weight anticancer agent housed in the same delivery system. It is interesting to note that

*Corresponding author: Salam Massadeh, King Abdulla International Medical Research Center, King Saud Bin Abdulaziz University for Health Sciences, Developmental Medicine Department, King Abdul Aziz Medical City, Ministry of National Guard health Affairs, Riyadh, KSA, Saudi Arabia, Tel: +966-11-429 1111; E-mail: massadehsa@ngha.med.sa

Received November 23, 2015; Accepted December 18, 2015; Published January 03, 2016

Citation: Massadeh S, Al-Aamery M, Bawazeer S, AlAhmad O, AISubai R, et al. (2016) Nano-materials for Gene Therapy: An Efficient Way in Overcoming Challenges of Gene Delivery. J Biosens Bioelectron 7: 195. doi:10.4172/21556210.1000195

Copyright: (C) 2016 Massadeh S, et al. This is an open-access article distributed under the terms of the Creative Commons Attribution License, which permits unrestricted use, distribution, and reproduction in any medium, provided the original author and source are credited. 


\begin{tabular}{|c|c|c|c|c|c|}
\hline $\begin{array}{c}\text { Type of Drug Delivery } \\
\text { System }\end{array}$ & Trade Name & Active Ingredient & Breakthrough & Disease & Year of Approval \\
\hline \multirow[t]{2}{*}{ PEGylated proteins } & Adagen ${ }^{\circledR}$ & PEGylated adenosine deaminase & $\begin{array}{l}\text { Increased circulation time and } \\
\text { reduced immunogenicity }\end{array}$ & $\begin{array}{l}\text { Adenosine deaminase } \\
\text { deficiency, Severe combined } \\
\text { immunodeficiency disease }\end{array}$ & FDA 1990 \\
\hline & Cimzia® & PEGylated antibody & $\begin{array}{l}\text { Increases hydrodynamic radius, } \\
\text { prolongs circulation and retention } \\
\text { time, decreases proteolysis, } \\
\text { decreases renal excretion }\end{array}$ & $\begin{array}{c}\text { Crohn's disease, rheumatoid } \\
\text { arthritis }\end{array}$ & FDA 2008 \\
\hline \multirow[t]{2}{*}{ Nanocrystals } & Emend® & Aprepitant as nanocrystal & $\begin{array}{l}\text { Increased bioavailability due to } \\
\text { increased dissolution rate. }\end{array}$ & Emesis, antiemetic & FDA 2003 \\
\hline & Rapamune $\circledast$ & $\begin{array}{l}\text { Rapamycin (sirolimus) as } \\
\text { nanocrystals formulated in tablets }\end{array}$ & & Immunosuppressant & FDA 2002 \\
\hline \multirow[t]{2}{*}{$\begin{array}{l}\text { Polymer-based nano- } \\
\text { formulations }\end{array}$} & Copaxone ${ }^{\circledR}$ & Glatiramer peptide & $\begin{array}{l}\text { Glatiramer is thought to divert } \\
\text { as a "decoy" an autoimmune } \\
\text { response against myelin }\end{array}$ & Multiple Sclerosis & FDA 1996/2014 \\
\hline & Genexol@ & Paclitaxel & Passive targeting via EPR effect & $\begin{array}{l}\text { Metastatic breast cancer, } \\
\text { pancreatic cancer (IV) }\end{array}$ & South Korea 2001 \\
\hline $\begin{array}{l}\text { Protein-drug } \\
\text { conjugates }\end{array}$ & Abraxane ${ }^{\circledR}$ & $\begin{array}{l}\text { Nanoparticles formed by albumin } \\
\text { with conjugated paclitaxel }\end{array}$ & $\begin{array}{l}\text { Passive targeting via EPR effect } \\
\text { and may increase endothelial } \\
\text { transcytosis }\end{array}$ & $\begin{array}{l}\text { Metastatic breast cancer, non- } \\
\text { small-cell lung cancer (IV) }\end{array}$ & FDA 2005 \\
\hline $\begin{array}{l}\text { Surfactant-based } \\
\text { nano-formulations }\end{array}$ & Estrasorb $^{\mathrm{TM}}$ & $\begin{array}{c}\text { Emulsion of estradiol in soybean } \\
\text { oil, polysorbate } 80 \text {, ethanol, and } \\
\text { water }\end{array}$ & Increase drug solubilization & $\begin{array}{l}\text { Hormone replacement therapy } \\
\text { during menopause }\end{array}$ & FDA 2003 \\
\hline $\begin{array}{l}\text { Metal-based nano- } \\
\text { formulations }\end{array}$ & NanoTherm ${ }^{\circledR}$ & $\begin{array}{l}\text { Aminosilane-coated } \\
\text { superparamagnetic iron oxide } 15 \\
\mathrm{~nm} \text { nanoparticles }\end{array}$ & Thermal ablation & $\begin{array}{l}\text { Local ablation in glioblastoma, } \\
\text { prostate, and pancreatic cancer } \\
\text { (intratumoral) }\end{array}$ & Europe 2013 \\
\hline \multirow[t]{2}{*}{ Virosomes } & Gendicine $\circledast$ & $\begin{array}{l}\text { Recombinant adenovirus } \\
\text { expressing wildtype-p53 }\end{array}$ & Targeted gene therapy & $\begin{array}{l}\text { Head and neck squamous cell } \\
\text { carcinoma }\end{array}$ & $\begin{array}{l}\text { People's Republic of } \\
\text { China } 2003\end{array}$ \\
\hline & Rexin-G® & $\begin{array}{l}\text { Gene for dominant-negative } \\
\text { mutant form of human cycline } \mathrm{G} 1\end{array}$ & $\begin{array}{c}\text { Targeted gene therapy Specificity } \\
\text { achieved by targeting exposed } \\
\text { collagen }\end{array}$ & For all solid tumors & Philippines 2007 \\
\hline
\end{tabular}

Table 1: Few examples of FDA approved polymer nanoparticles based therapies.

such approaches may also benefit from appropriate sequential release of two types of agent, although this consideration is in its infancy and is currently secondary to the considerable engineering challenges associated with the development of such nanostructured systems (Figure 1 and Table 1).

\section{Challenges of delivery of therapeutic siRNA}

SiRNA have great potential to be a leading therapeutic tool for several diseases. However, the major obstacle that stands in the way of realization of such therapies is the in vivo delivery of RNAi molecules, like the small interfering RNAs (siRNAs). Many intracellular and extracellular obstacles still need to be conquered in order to benefit from the full aptitude of this technology. The molecules are too impermeable and too metabolically labile to be delivered alone, hence it is essential to develop vectors with which these molecules may be both protected and facilitated in reaching the target site.

First of all, siRNA stability is highly negotiable, due to the extracellular degradation by enzymes located in serum and tissues, resulting in a short life time of the bare siRNAs in serum that can go up to one hour [34]. Hence, the targeting of therapeutic siRNAs is extremely challenging, as the siRNA faces many barriers before reaching their target cells to act on the gene silencing. Additionally, when the siRNAs are in the cell cytoplasm, they become susceptible to deterioration as a result of their contact with the intracellular RNAses. Secondly, another issue that should be taken into account when dealing with therapeutic siRNA is the off target silencing. Sometimes the specific silencing may suppress other genes than the ones of interest. Resulting in major undesirable mutations of gene expression, therefore, analytical bioinformatics methods are recommended. At this stage, siRNA design promises to considerably minimize and ultimately eliminate off-target silencing. Also, siRNAs may trigger immune responses by activating interferon responses resulting in cell death. Immune response is different from one cell to another, which makes it hard to predict the in vivo behavior without running in vitro experiments first. An optimal delivery strategy for siRNAs would be one that guarantees targeted delivery and high stability, a method that can protect the delivered material from undesirable immune response. In this project we will focus on the synthesis of a bio compatible delivery system that can specifically target the delivery of siRNAs, protect it from elimination and increasing the chances of the medical applications of siRNAs therapies. A trend that is pertinent to these discussions is the use of Nano composite systems, whereby more than one vector (a complexing molecule, a lipid or a synthetic polymer) may be combined into a Nano particulate system in order to elicit more than one advantage in delivery.

\section{Therapeutic siRNA}

The field of RNA interference (RNAi) started to gain much interest, since it was uncovered by Fire and Mello, around two decades ago. The standard understanding of the gene regulation has been transformed after the functional studies performed on C. elegans, where it has been found that double stranded RNAs were the reason of the gene silencing in C. elegans [62-65]. Subsequently, siRNAs have been found in plants and showed to direct sequence-dependent endo nucleolytic cleavage of the mRNAs that they regulate in mammalian cells [6668]. Moreover, some years later Elbashir. had effectively utilized synthetic siRNAs for gene silencing and they were able to verify the basic siRNA structure, offering the basics for optimizing RNAi applications $[69,70]$. Ever since, selective silencing of genes became possible. Selective gene silencing can be achieved by controlling the endogenous RNAi pathway with synthetic assemblies. This technique 


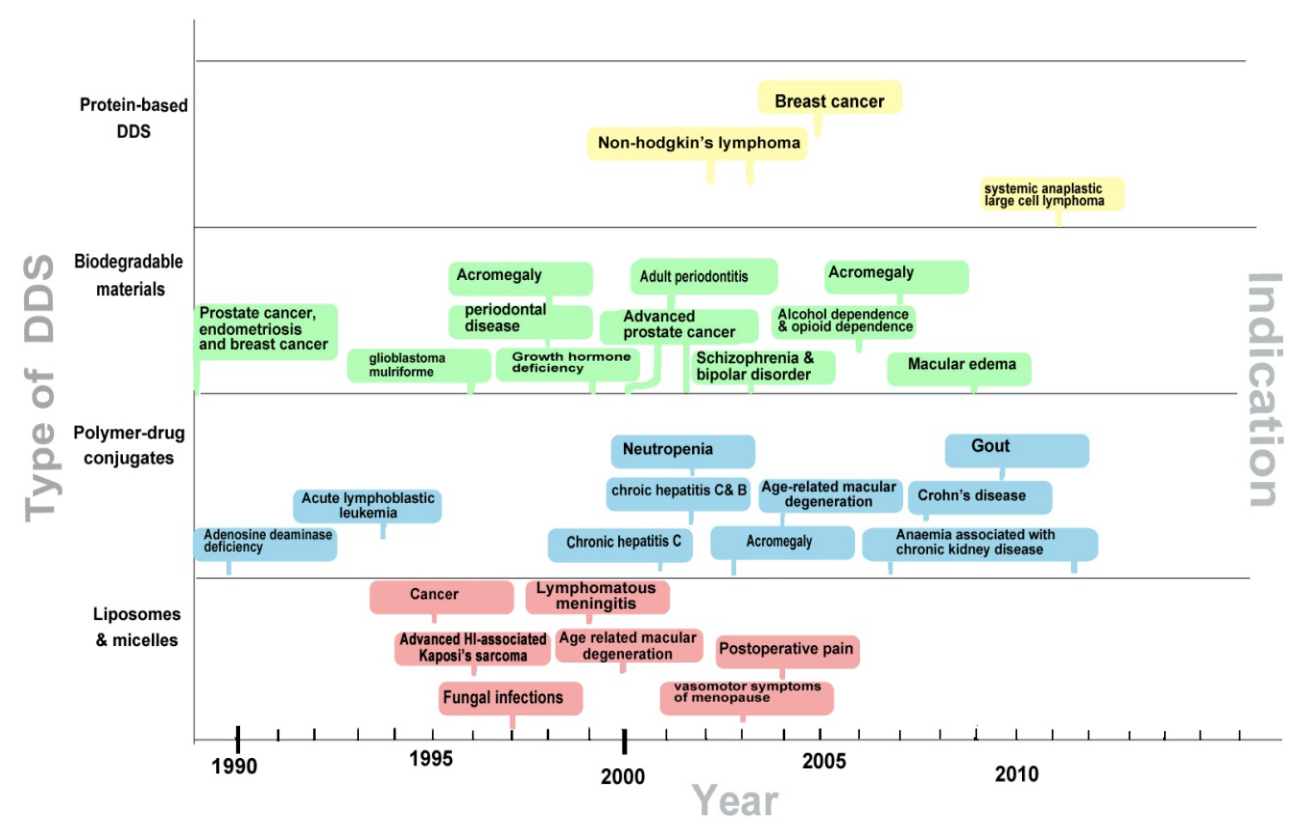

Figure 1: Different drug delivery systems and their use in therapeutics.

is becoming widely popular for the genetic functional studies, where it has resulted in promising therapeutic aptitude. However, the realization of using siRNAs as therapeutic agents is hindered by many challenges. siRNA Stability in serum is highly negotiable, siRNAs are liable to degradation by serum and tissue enzymes; resulting in a very short half-life ranging from several minutes to an hour $[68,69]$. In addition, microarray studies have shown that off-target silencing can be a result of the siRNA therapy, which leads to the suppression of noninterest genes. Off-target silencing may cause dangerous mutations of gene expression and undesirable cellular transformations. It has been shown that most off-target silencing is a result of homology with six to seven nucleotides in the "seed region" of the siRNA sequence [7174]. Also the use of siRNAs as therapeutics has been limited due to the activation of unexpected immune responses, that can lead to cell death in vitro $[75,76]$. The immune responses differ from one cell to another. Therefore, the in vivo immune reactions cannot be anticipated based on the in vitro work. The in vivo delivery of genetic is the major challenge that faces scientist when developing siRNA based therapies [76,77]. Virus-based delivery systems have been considered as an efficient mean of siRNA delivery. However, it could not be taken any further due to its fatal side effects; virus delivery can stimulate mutations, and trigger immunogenic and inflammatory responses [78]. Hence, alternative no viral delivery systems have been developed to replace the viral delivery of siRNA. Other non-viral delivery systems include direct chemical modification of siRNA, nanoparticles, and targeting moieties.

\section{Nanoparticles used in gene delivery}

Polymer nanoparticles: Polymer nanoparticles (PNPs) deliver genes or therapeutic proteins including drugs which can either be dissolved or encapsulated within them forming a nanoparticle and a Nano capsule respectively. PNPs can also deliver proteins to the targeted cells by entrapping them within its structure forming a Nano sphere. The delivered therapeutic proteins or drugs act by altering defective proteins or genes in the patient's cells. The size of

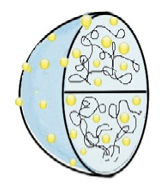

Nanosphere

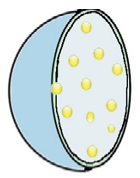

Nanocapsule

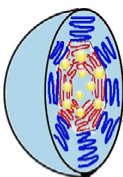

Nanomicelle
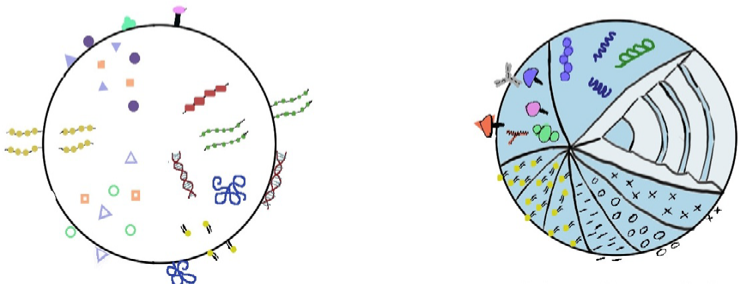

Figure 2: The structure of polymer nanoparticles.

the polymer nanoparticle could be tuned to enable these drugs and therapeutic protein to fit in. PNPs, like all nanoparticles are capable of regaining their size once inside the cell through the physiological change in $\mathrm{pH}$. Figure 2 below represents the structure of polymer nanoparticles. PNPs have been utilized in drug delivery, where they have shown high biocompatibility and high encapsulation capacity. They are great candidates for gene delivery, because they are highly stable and they offer controlled release of active ingredients. Also, PNPs can be used for targeted delivery by surface modification, and they allow the delivery of combined active materials. PNPs are synthesized from non-toxic biodegradable, biocompatible polymers like, Chitosan, cyclodextrin, polyethylene mine (PEI), poly(lactic-coglycolic) acid (PLGA), and dendrimers [69,75]. These polymers can be used on their own to synthesize (PNPs) also; they could be combined together to get better properties of nanoparticles (Figure 2). PNPs 
technology has revolutionized the field of biology and health services. It has facilitated the development of new treatment methods with improved efficacy for treating diseases which had once been viewed as incurable like genetic, immunological and neural disorders [36]. In some cases, the delivered genes act by enhancing the functions of the cells. Polymer nanoparticles are used to overcome the various challenges that have been encountered in using gene therapy [79]. Some genes have relatively long base sequences which make it difficult for them to be delivered to the desired sites. To fit into the target cell, the DNA must be condensed into the Nano structures, to permit their internalization within the cells80. Moreover, the nucleases in the target cells may also degrade the DNA being delivered. And because the gene and the carrier are usually conjugated, their separation at the point of delivery is sometimes difficult. In some cases, gene silencing may also arise as the target cells may act against the delivered genes. Putnam et al. have demonstrated that using polycations such as polyline can overcome the DNA size barrier as it "can condense DNA into toroidal nanostructures" to sizes less than $150 \mathrm{~nm}$ which can internalized within the cell. Researchers have also identified various ways in overcoming the challenge of separation of the DNA from the carrier. Using nanoparticles to conjugate the DNA, researchers have developed an effective way to ensure that the genes are delivered to the targeted cells (Figure 3) Mohammedi have synthesized DNA-Chitosan nanoparticles to deliver DNA to the Lung Epithelial cells [80,81]. Also, in 2014 Tang have utilized chitosan based (PNPs) Trimethylated chitosan has been synthesized as gene delivery systems, TMC-g-PCL/DNA polyplexes have shown high uptake efficiency than PEI/DNA polyplexes $[22,82]$. Plus, Das et al. have utilized PEI based nanoparticles to deliver siRNA to STAT3 in lung cancer, in vitro and in vivo [81]. Other research groups have also synthesized chitosan as the main targeting nanoparticles for siRNA delivery to treat different diseases like, lung cancer, ovarian cancer, pancreatic cancer and hepatocellular carcinoma [22,81-90]. In 2015, Bishop have utilized polymer coated gold nanoparticles for DNA and siRNA delivery, where this type of inorganic nanoparticles have shown good results in gene silencing [91]. Colombo et al. have synthesized hybrid lipid-polymer nanoparticles for siRNA delivering [92]. While, other up to date studies have shown the improved cancer treatments obtained with co delivery [90-96] (Figure 4).

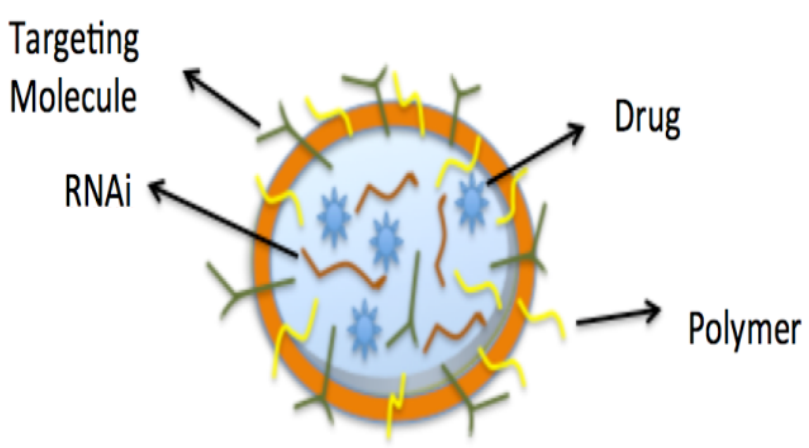

Figure 3: Schematic illustration of therapeutic siRNA loaded nanoparticle.

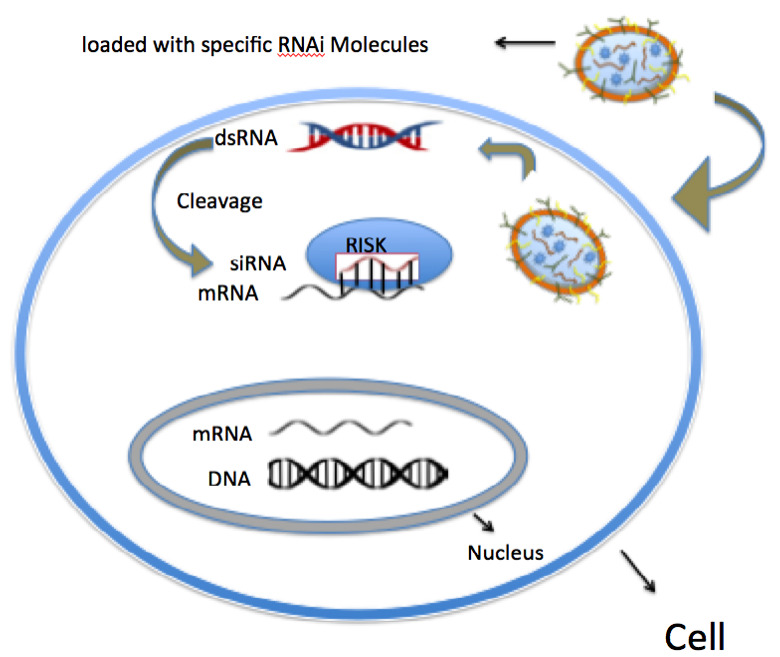

Figure 4: Illustration of the process of RNAi delivery using nanoparticles.

Dendrimers for gene delivery: Dendrimers are 1-10 nm, threedimensional globular synthetic macromolecules. Dendrimers are highly branched and characterized by monodispersity [97-101]. Synthesis of dendrimers was first discovered by two groups: Buhleier who focused on the construction of low molecular weight amines, and Tomalia who developed the divergent method tosynthesisedendrimers [102]. Dendrimers architecture consists of the core, branches and many terminal functional groups. The core is an atom or a molecule at the centre of the dendrimers with at least two identical chemical functions. From the core, branches with repeated units originate and spread, by having at least one branch junction, to form generations. These branches end with terminal functional groups at the surface of the dendrimers, which dictate the properties of the dendrimer macromolecule [97] (Figure 5). The most well studied dendrimer is polyamidoamine (PAMAM), which is characterized by high solubility and reactivity due to the presence of empty internal cavities and numerous functional groups at its periphery [103]. The properties of dendrimers, such as monodispersity, well-defined structure and the extensive quantity of surface functional groups, made them valuable tools to be used in gene delivery [104] (Figure 5).

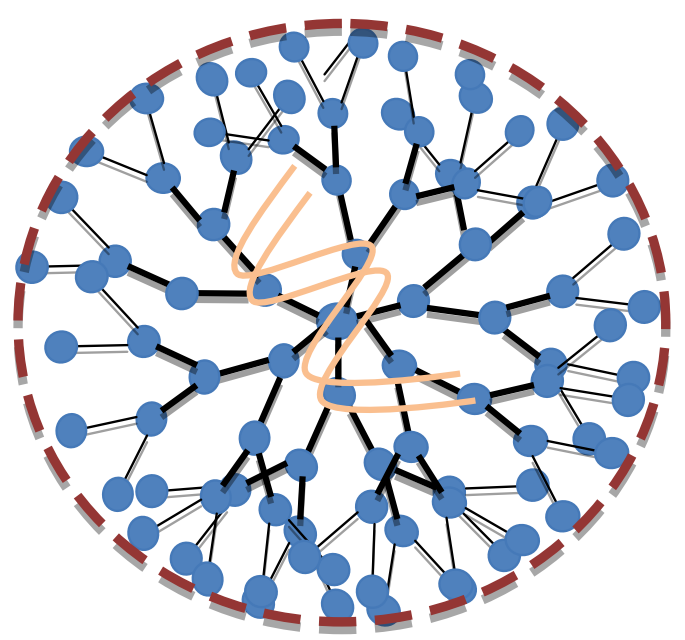

Figure 5: Structure of Dendrimers. 
Divergent and convergent methods of synthesis: Dendrimers are usually prepared using the divergent or the convergent method of synthesis. The divergent method of synthesis, developed by Tomalia, is a stepwise method starting from the core of the dendrimer and growing outwards towards the periphery. The multifunctional core reacts with the reactive group of monomer molecules giving the first dendrimer generation, This periphery molecule is then activated to react with the next set of monomers building up the dendrimer layer by layer (Figure 2) $[105,106]$. The multiplicity of the core depends on the number of molecules added to the core and is equal to the number of branches branching out of the core [107]. Polyamidoamine (PAMAM) dendrimers are prepared using this method of synthesis [105]. Problems that occur with the divergent method result from the side reactions and incomplete reactions of the end groups. These can be overcome by adding large excess quantities of the reagent to force the reactions to completion [106]. On the other hand, an advantage of the divergent methodliesin the ability to change the end groups of the periphery, which modifies the surface and properties of the dendrimer [105]. In contrast, structural uniformity is difficult to maintain with the divergent approach as the number of reactions increases exponentially with each step $[108,109]$. Hire demonstrated a divergent approach to synthesis "aliphatic ester dendrimersby anhydride coupling" using only a small excess of the reagent and only extraction and precipitation as a purification method. The convergent method of synthesis, developed by Hawker and Fréchet, is a stepwise method is initiated from the terminal groups and builds up towards the interior going to the core (Figure 4) [106]. This approach was developed to overcome weaknesses, such as the low reactivity, of the divergent method [105]. An advantage of the convergent method is the faster reaction rate due to the minimal reactive sites available during the proliferation process. Another advantage is an advanced purification process due to the large "molecular difference" between the end product and the reactant, which leads to an improved separation during purification [105]. On the other hand, the convergent method displays a disadvantage in the inability to produce high generations due to steric hindrance in the reaction between the dendrons and the core [110]. "Hypercores" and "branched monomers" is an advanced method that accelerates the rate of dendrimer synthesis and involves the pre-assembly of oligomeric species that are linked together to generate dendrimers. The "double exponential" is another approach, which begin with a single starting material to prepare monomers for both the divergent and convergent methods. These two products then react to give an "orthogonally protected trimer", which acts as the repeating unit in this growth. Moreover, lego chemistry method was developed by Tomalia and Svenson to simplify the duration and cost of dendrimer synthesis. It involves the preparation of phosphorus dendrimers by employing of highly functionalized cores and branched monomers. This allows the multiplication of terminal functional groups from 48 to 250 in just one step $[97,111]$. The click chemistry method was developed to produce higher purity and yield compared to the divergent method. It involves the spontaneous synthesis of two monomeric units with complimentary functions avoiding the use of activating agents and reducing the duration of synthesis. This method was successful in the production of triazoledendrimers [111,112] (Figure 6).

Dendrimers for gene delivery: Dendrimers are a great tool for gene delivery as they can interact with DNA, RNA and antisense oligonucleotide through electrostatic interaction to form complexes that condense the nucleic acid [113]. Hyperbranched dendrimers are more suitable to be used as gene delivery tools than more structured dendrimers as their flexibility allows them to form more compact

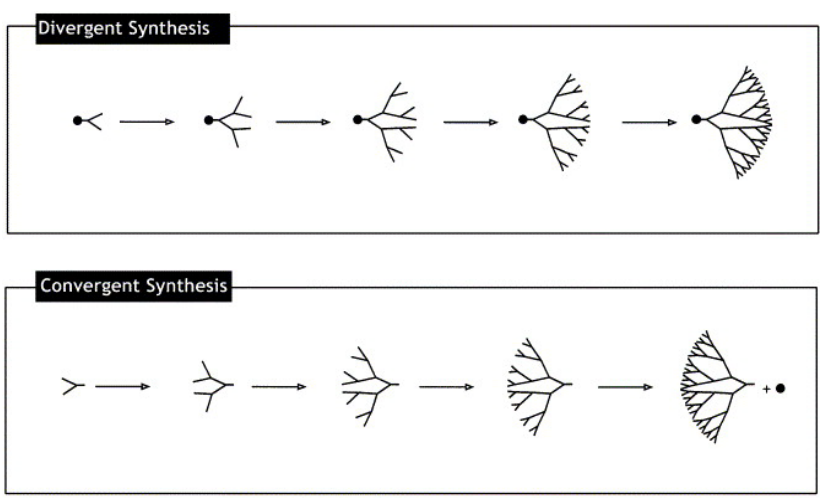

Figure 6: Methods of Synthesis of Dendrimers. a. Divergent synthesis begins from the core and builds up to the periphery. b. Convergent synthesis starts from the branches and builds up inwards toward the core [112].

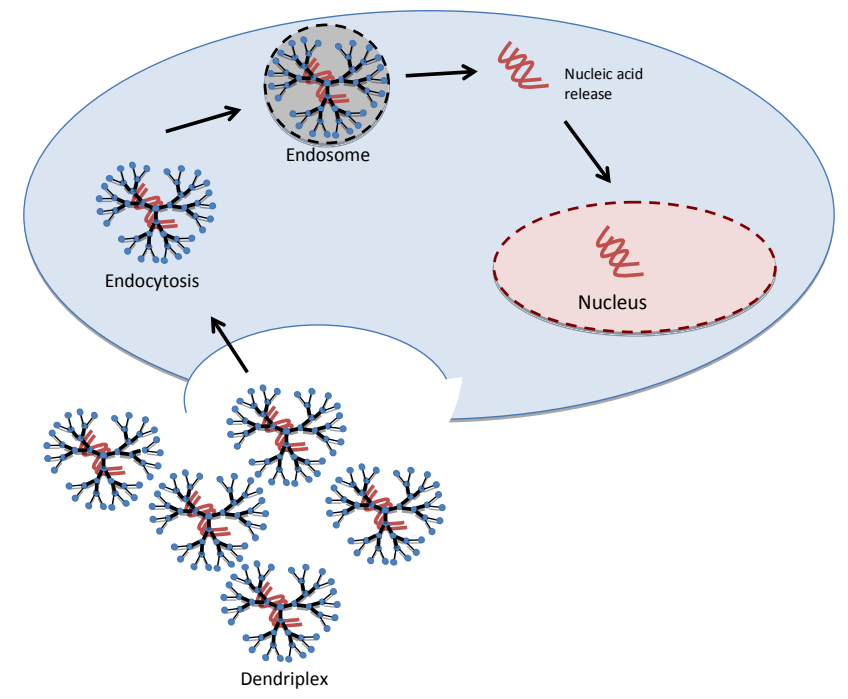

Figure 7: Dendrimers-mediated gene delivery.

complexes with DNA [114]. Under specific physiological and chemical conditions, dendrimes form polycations, which are able to bind to the negatively charged nucleic acid. As this dendrimer-nucliec acid complex needs to cross the epithelia to get to its target, it is required to have a positive net charge to enable the cellular uptake of the complex through its binding to the negatively charged cell membrane. Generally, high generation dendrimers are more toxic than low generation dendrimers. Therefore, the major factors affecting the permeability of the dendrimer-gene complex are the surface charge, concentration, generation time and surface modifications [104] (Figure 7). The positively charged dendrimer-nucleic acid complex (dendriplex) binds to the negatively charged cell membrane and is taken up by endocytosis forming an endosome. The endosome destabilises due to the sponge effect of the dendrimer, releasing the nucleic acid to the cytoplasm. Nucleic acid is then taken up by the nucleus where it is replicated.

Polyamidoamine (PAMAM): The six-generation PAMAM dendrimers are widely used dendrimers as vectors for gene delivery. PAMAMstructure shows a high density of amines in the periphery, which enables the condensation of nucleic acid. On the other hand, the inner amines enable efficient endosomal escape through the proton sponge 
effect [115], which is the resistance of cationic carriers that comprise a secondary or tertiary amine group to endosomal acidification through the absorption of protons. These cationic dendrimers absorb protons to below the physiological $\mathrm{pH}$, which in turn delays the lysosomal fusion to the endosome. This prevents the degradation of nucleic acid and allows the accumulation of counter-ions like $\mathrm{Cl}$ - in the endosome leading to the endosome rupture and the release of its content into the cytoplasm due to vesicular swelling [116]. According to Braun [117], dendrimers with higher generations show better gene transfer than those with lower generations [117]. However, higher generations of the PAMAM dendrimers show higher toxicity due to the increased nonbiodegradability. Nevertheless, it has been shown that six generations PAMAM dendrimers are the most efficient for gene delivery [104]. Modified PAMAM dendrimers are the most commonly used for the delivery of DNA and siRNA. A study by Tang showed that PEG (polyethyl glycol) conjugated PAMAM dendrimers has dramatically decreased cytotoxicities than non-PEG conjugated PMAM dendrimers. It also demonstrated that PEG-conjugated dendrimers protected siRNA from being digested and gave high transfection efficiency [118]. Although PEGylated, hyper branched PAMAM dendrimers showed a significant reduction in cytotoxicity, it also demonstrated a significant decrease in gene delivery efficiency compared to unmodified hyper branched PAMAM dendrimers. However, a mixed system that is composed of $30 \%$ modified (PEGylated) hyper branched PAMAM and $70 \%$ unmodified hyper branched PAMAM dendrimers improves gene delivery efficiency significantly while maintaining low cytotoxicity [119]. Acetylation and internal quaternization of PAMAM dendrimers is another modification that has been shown to decrease cytotoxicity in addition to genotoxicity, formation of micronuclei, of the dendrimers. This modification resulted in a neutral surface dendrimer with cationic charges inside the dendrimer, however the conformed dendrimers resulted in the formation of condensed spherical SiRNA polyplex, which protects the nucleic acids from degredation and improved their cellular internalization [120].

Polypropylenimine (PPI): Polypropylenimine (PPI) dendrimers are ideally suited for DNA binding and gene delivery, as they are comprised of $100 \%$ protonable nitrogen [121]. Schatzlien showed that gene delivery using PPI dendrimers demonstrated preferential expression of genes in liver, as opposed to other organs, which facilitate the specific use of it, for example in targeted cancer therapy [122]. Moreover, it has been shown that modification of PPI dendrimers would provide more effective intracellular delivery of the gene. Kim has shown that conjugation of PPI with arginine resulted in low toxicity and high transfection efficiency [123]. Furthermore, PPI dendrimers has also been used for siRNA delivery as shown by Tartula. Where PPI dendrimers were condensed with siRNA to form particles, that are caged with dithiol, and coated with PEG exhibited reduced genotoxicity, increased siRNA cellular bioavailability and stability in plasma, which in turn provided efficient gene silencing [120,124]. Russ have shown that although the generation 2 (G2) plasmid DNAPPI complex (polyplex) demonstrated lower cytotoxicity than the G3 polyplexes,polyplexes of G2 exhibited lower transfection efficiency than the G3 ones. Moreover, grafting the G2 and G3 PPI polyplex with oligoethyleninime(OIE) showed enhanced transfection efficiency compared to the unmodified counterpart [125].

Polyethylenimine (PEI): PEI dendrimers are water-soluble polymers that can interact with the DNA, because its positively charged, and protect DNA from degradation; which makes them a great delivery tool for siRNA and DNA [126], however some studies show that PEI is less effective in siRNA delivery due to the reduced electrostatic interaction resulted by the short length of siRNA. PEI exerts the proton sponge effect to release the nucleic acid into the cytoplasm [127]. In 2008, Intra and Salem studied the gene transfection efficiency of PEIpDNA in vivo and in vitro and showed that the branched PEI-pDNA structures displayed greater efficiency in vitro, whereas linear PEIpDNA structures have shown a greater efficiency in vivo when injected intraperitoneally. Moreover, differences in PEI nitrogen: pDNA phosphate ratios also had an impact on transfection efficiency [126].

Other types of dendrimers: Glyodendrimers, which are dendrimers that are incorporated with carbohydrates, has shown a great potential in targeted gene delivery [104]. Cyclodextrins are cyclic oligosaccharides that are composed of a hydrophilic exterior and hydrophobic interior. Wada showed that mannose-conjugated a-cyclodextrins PAMAMs demonstrated high transfection efficiency in mouses' kidney 12-hourpost intravenous administration, compared to the unmodified dendrimers and $\alpha$-cyclodextrins. Efficient gene delivery in addition to low toxicitymakes it an ideal non-viral vector [128]. Moreover, Arima reviewed "sugar-appended" dendrimers and demonstrated that mannosylateda-cyclodextrinsdendrimers exhibit high transfection efficiency possibly due to the increased protection of plasmid DNA from methylation compared to unmodified dendrimers. Additionaly increased gene activity displayed by galactosylatedacyclodextrinsdendrimers may be due to intracellular trafficking and/or the stability of plasmid DNA [129]. Futhermore, peptide dendrimers, which are dendrimers that contain peptide bonds, have also been reported for gene delivery. A study by Luo synthesised poly(L-lysine) dendrimers as vectors for gene transfection in vitro and showed that the dendrimer-pDNA complex protected pDNA from degradation by nucleases with an efficiency that is stronger than the commercially available branched PEI. When compared to PEI, generation 5 (G5) of the dendrimers displayed similar transfection efficiency but lower toxicity to cultured cells [130]. Moreover, Arginine functionalized peptide dendrimers, synthesized using click chemistry, also showed high transfection efficiency in vitro independent of serum compared to PEI, specially generation dendrimers which displayed high transfection efficiency in vitro and in vivo making it ideal for gene delivery [128] Table 2 below lists some of the approved dendrimers based therapies, used in genetic material delivery (Table 2).

Liposomes for gene delivery: Liposomes are small vesicle-like structures that are formed by self-assembly through lipids energetic interactions. Each phospholipid consists of a hydrophobic hydrocarbon tails, hydrophilic head group and a linker bond that joins the hydrophilic head and hydrophobic tail [131-133]. Liposomes possess properties such as reduced toxicity, safe preparation and reduced risk of immunological rejection, which enable its use for non-viral gene delivery [134]. Cationic lipids, which attain amine groups in the polar head, are more commonly used for gene delivery whereas anionic liposomes uses are constricted to other therapeutic macromolecules, because the positive charge of the liposomes binds to the negatively charged nucleic acids much easier [132]. The use of cationic liposomes for gene delivery is advantageous as it is biodegradable after administration in vivo, biocompatible and its surface can be diversely modified when using pegylated lipids [135]. The lipoplex formation is mainly enhanced by electrostatic reactions linking the DNA phosphate backbone and the positively charged polar head group of the liposome [136]. The size of the lipoplexes is determined by the ratio of cationic lipid-to-DNA charge during preparation. Relatively neutral charge ratios with slight excessive positive charges result in the formation of large aggregates, whereas high positive or negative charges results in the formation of relatively small aggregates 


\begin{tabular}{|c|c|c|}
\hline Dendrimer & Commercially Available & Applications \\
\hline \multirow{5}{*}{ PAMAM } & \multirow{5}{*}{$\begin{array}{l}\text { STARBURST® dendrimers (Sigma } \\
\text { Aldrich) }\end{array}$} & - In vitro transfection of liver (HepG2) and colon (CT26) cells \\
\hline & & - In vivo gene delivery \\
\hline & & - In vitro transfection into mesenchymal stem cells \\
\hline & & $\begin{array}{l}\text { - Formation of stable PAMAM-transferrin conjugate to form stable dendriplexes with plasmid } \\
\text { DNA and improved gene delivery to HeLa, HepG2 and CT26 cell lines. }\end{array}$ \\
\hline & & $\begin{array}{l}\text { - Delivery of sticky siRNA in vivo and in vitro to prostate cancer model using triethanolamine } \\
\text { (TEA)-core PAMAM dendrimer of generation five. }\end{array}$ \\
\hline \multirow{5}{*}{ PPI } & \multirow{5}{*}{$\begin{array}{l}\text { Astramol (Dutch State Mines (DSM) } \\
\text { Netherlands and Aldrich Chemical } \\
\text { Company) }\end{array}$} & $\bullet$ siRNA delivery \\
\hline & & - Successful gene expression in liver rather than other organs \\
\hline & & - Accumulation in tumor tissue and induction of tumor- specific gene expression \\
\hline & & - PPI-collagen conjugates used as a scaffold for corneal tissue engineering. \\
\hline & & - Generation 4 and 5 PPI dendrimers to knockdown mRNA in A549 human lung cancer cells \\
\hline \multirow{3}{*}{ PEI } & & - Gold standard for plasmid DNA delivery \\
\hline & & - Delivery of short hairpin RNA (shRNA) to retinal ganglion cells \\
\hline & & - Pulmonary gene delivery in vivo \\
\hline Glycodendrimers & & - In vivo transfection of mannose-conjugated $\alpha$-cyclodextrins in mouse kidney \\
\hline \multirow{3}{*}{ PLL } & & - In vivo transfection of generation 6 PLL-plasmid injected intravenously in mice \\
\hline & & - In vitro transfection in different cells \\
\hline & & - Effective knockdown of GAPDH in rat hepatoma (H4IIEC3) cells with low cytotoxicity. \\
\hline Carbosilane & & - 2G-NN16 and 2G-03NN24 carbosilanedendrimers in gene therapy of HIV infection \\
\hline
\end{tabular}

Table 2: Commercially available dendrimers used as vectors for gene therapy.

[136,137]. The most commonly used cationic liposomes utilized for the delivery of nucleic acids include DOTMA, DOTAP and DC-Chol. First reported liposomes by Felgner was N-(1-(2,3-dioleyloxy)propyl)$\mathrm{N}, \mathrm{N}, \mathrm{N}$ trimethyl ammonium chloride) (DOTMA), which consists of a monovalent quaternarey amine head connected to two hydrocarbon tail via an ether group [134]. Subsequently, [1,2-bis(oleoyloxy)3-(trime- thylammonio)propane] (DOTAP), which consist of a quaternary amine group linked to a glycerol backbone and two oleoyl chains, was repored by Leventis and Silvius. The ester bonds in DOTAP provides biodegradability and reduce toxicity because ester bonds are hydrolysable [132]. Furthermore, the cholesterol based liposome, $3 \beta\left[N-\left(N^{\prime}, N^{\prime}\right.\right.$-dimethylami-noethane)-carbamoyl] cholesterol(DCChol), has been synthesized using cholesterol chains as hydrophobic tails as it provides stability and biocompatibility [132,138]. More recently, new cationic liposome, DODAG $\left(\mathrm{N}^{\prime}, \mathrm{N}^{\prime}\right.$-dioctadecyl-N-4,8diaza-10-aminodecanoylglycine amide), has been reported for efficient transfection of pDNA to multiple cell lines including Hela cells [139]. Transfection efficiency of liposomes is affected by the net charge of the lipoplex in addition to the size of the lipoplex. It has been shown that relatively large liposomes (0.4-1.4 um) has a greater transfection efficiency than smaller liposomes [136-140]. Moreover, it has been proven that PEG modification of liposomes increases the stability of liposomes in blood and improves its pharmacokinetics and transfection efficiency [141]. This prolonged circulation time was shown to be influenced by the length of the acyl chain of the PEG lipid as shown by 142 that explained that longer acyl chains demonstrates a higher transfection efficiency than shorter acyl chains or unsaturated chains. PEG coating also lowers protein binding to the surface of the liposomes, which reduces uptake by macrophages. Higher blood circulation is also influenced by the molar percentage of PEG lipids, however higher percentage also hamper cellular uptake and cytoplasmic deposition of siRNA [142,143].

Magnetic nanoparticles: Paramagnetic nanoparticles have been used as drug carriers. Their accumulation is guided in target tissues using strong magnetic fields, and they has successfully used in cancer treatment. Similarly, the same technique has been applied to gene vectors; a high throughput magnetofecion was able to offer a new tool for gene therapy that overcomes the drawbacks of in vivo gene therapy. Magnetofecion (Figure 8) has improved the efficacy of conventional transfection methods in vitro and in vivo. The first application of magnetic nanoparticles in gene therapy was reported by Scherer et al. [143]. They have associated gene vectors with superparamagnetic iron oxide nanoparticles. In vitro and in vivo experiments have shown that gene delivery and targeting was enhanced by the magnetic force within the iron oxide nanoparticles. Moreover, in 2005 Morishita have incorporated magnetic nanoparticles into unique vectors called "HVJ-E (hem agglutinating virus of Japan-envelope)", where the magnetic nanoparticles have improved the transfection efficiency in in vitro studies [141]. Advances in technology have recognized magnetic nanoparticles as therapeutically reliable delivery systems, that is able to both enhance transfection of cargo as well as allow for target specific delivery through external application of a magnetic gradient onto the desired area [144]. The term "magnetofection" coined by Scherer refers to this method of magnet-assist gene delivery $[145,146]$. The gene is joined to a magnetic particle or transporter, consisting of an iron-oxide encapsulated within a polymer or metallic shell [143]. Alternatively, the particle can be dispersed in a polymer matrix. The shell or matrix may then be functionalized through attaching amines, biotin, streptavidin or antibodies in order to achieve maximum efficiency. Nanoparticles used for in vitro reactions are layered with polyethylene mine (PEI), which is able to adhere to DNA by means of electromagnetic interaction. In addition, the highly positive charge of PEI also further supports DNA transfer into cells as well as promotes dissociation of DNA complexes from endosomes through a proton sponge effect that ruptures the endosome $[147,148]$ which relies on coating iron oxide nanoparticles with cationic polymers and particularly poly-ethylenimine (PEI) [149]. The few studies mentioned above represent most of the work done combining gene therapy and magnetic nanoparticles. Although the previous studies have shown an enhancement in transfection, with such promising results, not many investigations have been reported recently (Figure 8).

Gold nanoparticles: Gold nanoparticles (AuNPs), are known to be 


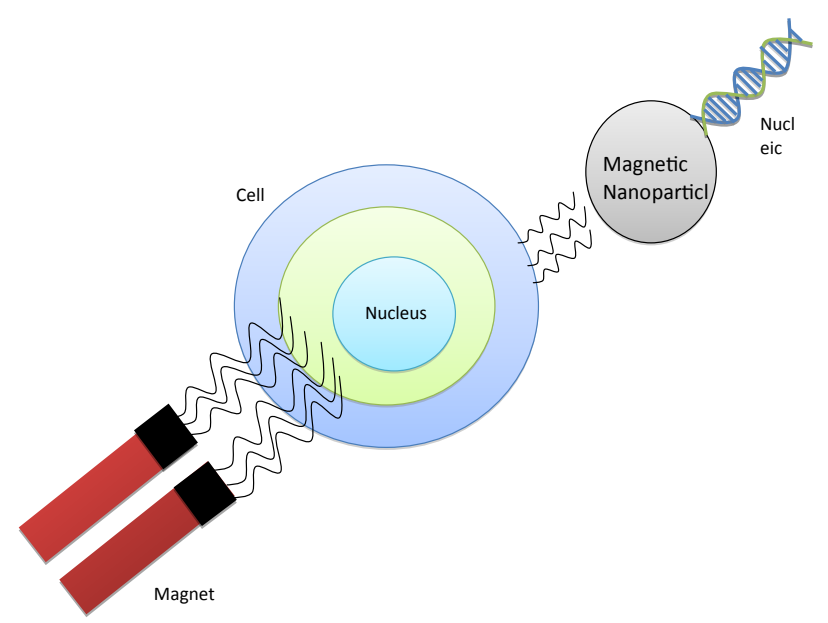

Figure 8: Schematic illustration of the process of Magnetofecion. The delivery of genetic material using magnetic nanoparticles.

appropriate gene delivery vehicles. The optical and physiocochemical properties that allow for easy transfection into cells as well as their unique biocompatibility that make them non-toxic. Moreover, AuNPs can be easily modified and custom made for optimum delivery and specificity. Several issues must be taken into consideration for successful gene delivery, particularly effective cargo condensation, cellular uptake, DNA stability and prevention of degradation from nucleases as well as efficient delivery of DNA into the nucleus for expression [147-151]. The very first studies used DNAs natural structure as a blue print for designing AuNPs that are able to fulfill the necessary requirements, using spherical gold nanoparticles that are functionalized with amino acids thus resembling histones in size, shape and surface area. Several studies have shown lysine coated AuNPs produce more potent transfection vectors, that are able to condense DNA; for instance NP-LysG1 proved to be 28 more successful than polylysineheadgroups in reporter assays $[111,149,150,152,153]$. The superiority of lysine Dendron-functionalized AuNPs as delivery vectors can be attributed to their biometric design that makes their size similar to that of nucleosome core proteins $(\sim 6 \mathrm{~nm})$ as well as forming electrostatic bonds with the phosphate backbone of DNA [149]. Modification of head groups attached to nanoparticles also serve to protect DNA from degradation cationic quaternary and trimythl ammonium-functionalized nanoparticles (NP-TMA) protected electrostatically bound plasmid DNA from DNase digestion. Most importantly, these additions are safe and display no cytotoxicity or unwanted immune responses $[154,155]$. The control of the transfection and release of nucleic acids, has been achieved by binding gold-thiolate on the surface of the AuNPs that are manipulated via intracellular glutathione levels. Ligands bound on the surface of the AuNPs are exchanged with the cellular glutathione (GSH), which will result in altering the AuNPs surface charge and loosening the nucleic acids bound to the nanoparticles [150]. Moreover, different GSH levels provide a mechanism for transfection regulation increasing efficiency in a concentration dependent fashion. Conversely, suppression of glutathione by L-buthionine-[S,R]-sulfoximine (BSO) treatment over $24 \mathrm{~h}$ caused lower transfection efficiency [154-157]. Furthermore, AuNPs may also be used in combination with other nano particles in order to improve and enhance efficiency. A more recent experiment combined both dendrimers and AuNPs, the unique morphology has maintained the three dimensional spherical form of dendrimers while increasing the number of binding sites [34,69]. These unique Au DENPs have a generation 5 PAMAM dendrimers with amine groups on their periphery, significantly augmented pDNA compaction and eventually improved nucleic acid delivery with a 100 times enhanced gene transfection efficiency than the conventional DENPs . Recently, a study using ethylenimine-conjugated AuNPs (PEI2-AuNPs) as a vector for corneal gene therapy demonstrated efficient delivery of BMP7 gene that significantly attenuated corneal fibrosis in an in vivo model. Furthermore, PEI2-GNPs exhibited minimal cytotoxicity and did not trigger an immune response [158] . More recently, a 2015 study have discussed the co delivery of and DNA and siRNA using hybrid coated gold nanoparticles [156,157].

Quantum dots for labeling genetic material: Quantum dots (QDs) are crystalline nanoparticles with electrical and mechanical properties. QDs are highly luminescent, colloidal semiconductor Nano crystals. QDs have unique size-dependant properties, which make them highly attractive for applications in catalysis, phosphors, photovoltaic, light emitting diodes (LEDs) and biological labeling. The main appealing feature of semiconductor NCs, are their mesoscopic properties that differentiates them from bulk crystals. Besides, it is possible to bind quantum dots to proteins and receptors to check with which molecules they interact and to explore their location in the cell. Hence, QDs are used in biomedical applications because of their unique tunable optical properties $[12,16,155]$. Made of semiconductor, quantum dots can be excited which makes them suitable not only in monitoring the genes; they are capable of overcoming the challenge of gene silencing. During excitation, the quantum dots attain a higher energy state. This usually occurs during preparation; before being used for gene delivery. However, upon entering the cell the differential $\mathrm{pH}$ causes the QDs return to a lower energy state. The photons lost during such process leads to fluorescence. The produced light bands are visible to the naked eye. They can be viewed eve within organic matter; that is, quantum dots have bioluminescence qualities. Therefore, their optical and electrical properties allow for bioluminescence. Their small sizes make them suitable for delivering genes; they can regain their sizes while in the cell. Semiconductor quantum dots (QDs) can be used to deliver genes such as RNA interference (RNAi) which is capable of silencing genes in the cell which either cause a disease or interfere with the activation of the delivered genes and synthesis of the therapeutic proteins [157-159]. The ability of the quantum dots to emit light in the visible spectrum of various wavelengths even within biological organisms make the nanoparticles important for tracking and monitoring the genes during the transfection. Such tracking and monitoring have provided important clues on how and when activation and silencing of the genes occur $[160,161]$. Moreover, they significantly reduce the degradation of the genes by the DNA nucleases. Additionally, QDs have been used as siRNA delivery vehicles to silence a target gene, and as fluorescent probes to analyze intracellular imaging in vivo. QDs-SiRNA complex has targeted HPV18 E6 oncogene which has eventually inhibited the growth of HeLa cells. QD-siRNA complexes serve as dual-modality; providing an optical and tool for live cell imaging and localization of QDs throughout the SiRNA delivery and transfection (Figure 9) [161].

\section{Conclusion}

In summary, gene therapy is one of the most exciting and revolutionary new approaches to therapies. The application of gene therapy has been hindered due to many reasons. It has been shown that therapeutic Nanomaterials could be utilized as promising tools to specifically deliver siRNA and mRNA to the target cells. Polymeric nanoparticles are the most commonly used type of nanoparticles used 


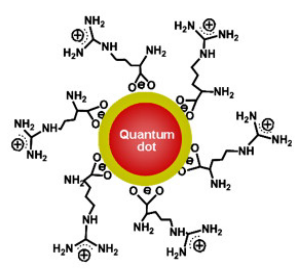
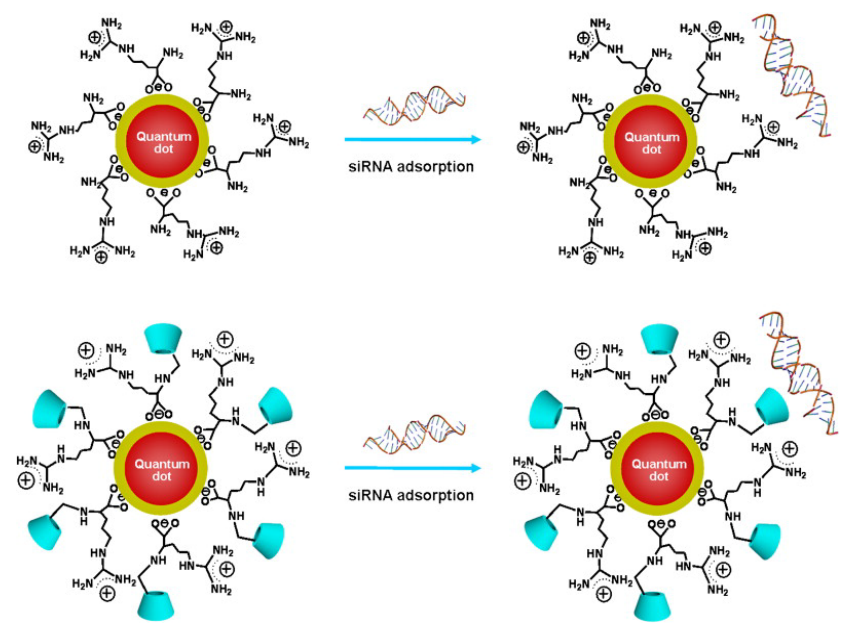

Figure 9: The adsorption of siRNA on the surface of differently functionalized QDs [161].

in gene therapy due to their biocompatibility and their ability to deliver the genetic material to its target with loss of its function. Nonetheless, the realization of such therapies is still debatable. Moving from the lab to the clinic has not yet been achieved. Hence, research in this area still requires in depth studies that involve functional assays. First, the nanomaterial should be designed and characterized; secondly, verify routes of administration of the therapies and finally, simplifying the synthesis methods making it trouble-free to expand at an industrial level.

\section{Acknowledgements}

We would like to acknowledge King Abdullah International Medical Research Center (KAIMRC), for the generous funding of this work through grant RC12/10. The authors would like to thank Ms. Dana Algudairi for sketching some of the graphs in this manuscript.

\section{References}

1. Fenyman R (1959) There is Plenty of Room at the Bottom.

2. Drexler KE (1992) Nanosystems: Molecular Machinery, Manufacturing, and Computation.

3. Drexler KE (1986) Engines of creation: The Coming Era of Nanotechnology.

4. Drexler KE (1981) Molecular engineering: An approach to the development of general capabilities for molecular manipulation. Proc Natl Acad Sci USA 78: 5275-5278.

5. Taniguchi N (1978) Nanotechnology: Materials Processing with an Atomic or Molecular Size Working. Unit. Kinzoku Hzomen Gijutsu 29: 220-231.

6. Ozin GA, Cademartiri L (2009) Nanochemistry: what is next? Small 5: 1240 1244.

7. Medintz IL, Berti L, Pons T, Grimes AF, English DS, et al. (2007) A reactive peptidic linker for self-assembling hybrid quantum dot-DNA bioconjugates. Nano Lett 7: 1741-1748.

8. Green M (2004) Semiconductor quantum dots as biological imaging agents. Angew Chem Int Ed Engl 43: 4129-4131.

9. Mulvaney P, Liz ML, Giersig M, Ung T (2000) Silica encapsulation of quantum dots and metal clusters. J. Mater. Chem 10: 1259-1270.

10. Meng YS, Dompablo MEA (2009) First principles computational materials design for energy storage materials in lithium ion batteries. Energy Environ. Science 589-609.

11. Sun TM, Wang YC, Wang F, Du JZ, Mao CQ, et al. (2014) Cancer stem cell therapy using doxorubicin conjugated to gold nanoparticles via hydrazone bonds. Biomaterials 35: 836-845.
12. Li C, Zhang Y, Wang M, Zhang Y, Chen G, et al. (2014) In vivo real-time visualization of tissue blood flow and angiogenesis using Ag2S quantum dots in the NIR-II window. Biomaterials 35: 393-400.

13. Wang J, Lu Y, Peng F, Zhong Y, Zhou Y, et al. (2013) Photostable waterdispersible NIR-emitting CdTe/CdS/ZnS core-shell-shell quantum dots for highresolution tumor targeting. Biomaterials 34: 9509-9518.

14. Mattoussi H, Palui G, Na HB (2012) Luminescent quantum dots as platforms for probing in vitro and in vivo biological processes. Adv Drug Deliv Rev 64 138-166.

15. Kim EY, Schulz R, Swantek P, Kunstman K, Malim MH, et al. (2012) Gold nanoparticle-mediated gene delivery induces widespread changes in the expression of innate immunity genes. Gene Ther 19: 347-353.

16. Sabharwal N, Holland EC, Vazquez M (2009) Live cell labeling of glia progenitor cells using targeted quantum dots. Ann Biomed Eng 37: 1967-1973.

17. Berry C, Harianawalw H, Loebus C, Oreffo RO, Fuente J (2009) Enhancement of Human Bone Marrow Cell Uptake of Quantum Dots using Tat Peptide. Curr Nanosci 5: 390-395.

18. Hama Y, Koyama Y, Urano Y, Choyke P, Kobayashi H (2007) Simultaneous two-color spectral fluorescence lymphangiography with near infrared quantum dots to map two lymphatic flows from the breast and the upper extremity Breast Cancer Res. Treat 10: 23-28.

19. Cywinski PJ, Moro AJ, Löhmannsröben HG (2014) Cyclic GMP recognition using ratiometric $\mathrm{QD}$-fluorophore conjugate nanosensors. Biosens Bioelectron 52: 288-292.

20. Brunetti V, Chibli H, Fiammengo R, Galeone A, Malvindi MA, et al. (2013) InP/ $\mathrm{ZnS}$ as a safer alternative to CdSe/ZnS core/shell quantum dots: in vitro and in vivo toxicity assessment. Nanoscale 5: 307-317.

21. Massadeh S, Nann T (2014) InP/ZnS Nanocrystals as Fluorescent Probes for the Detection of ATP. Nanomater Nanotechnol 4.

22. Tang S, Huang Z, Zhang H, Wang $Y$, Hu Q, et al. (2014) Design and formulation of trimethylated chitosan-graft-poly(Î $\mu$-caprolactone) nanoparticles used for gene delivery. Carbohydr Polym 101: 104-112.

23. Liu J, Huang Y, Kumar A, Tan A, Jin S, et al. (2014) pH-sensitive nano-systems for drug delivery in cancer therapy. Biotechnol Adv 32: 693-710.

24. Conde J, Larguinho M, Cordeiro A, Raposo LR, Costa PM, et al. (2014) Goldnanobeacons for gene therapy: evaluation of genotoxicity, cell toxicity and proteome profiling analysis. Nanotoxicology 8: 521-532.

25. Wang F, Willner B, Willner I (2013) DNA nanotechnology with one-dimensional self-assembled nanostructures. Curr Opin Biotechnol 24: 562-574.

26. Lin EH, Chang HY, Yeh SD, Yang KY, Hu HS, et al. (2013) Polyethyleneimine and DNA nanoparticles-based gene therapy for acute lung injury. Nanomedicine 9: 1293-1303.

27. Vimal S, Abdul Majeed S, Taju G, Nambi KS, Sundar Raj N, etal. (2013) Chitosan tripolyphosphate (CS/TPP) nanoparticles: preparation, characterization and application for gene delivery in shrimp. Acta Trop 128: 486-493.

28. Ahmed M, Douek M (2013) The role of magnetic nanoparticles in the localization and treatment of breast cancer. Biomed Res Int 2013: 281230.

29. Zheng SW (2012) Preparation and characterization of magnetic gene vectors for targeting gene delivery. Appl. Surf. Sci 259: 201-207.

30. Yoshizawa S (2012) Micro and nanotechnological tools for study of RNA Biochimie 94: 1588-1594.

31. Xu J, Ganesh S, Amiji M (2012) Non-condensing polymeric nanoparticles for targeted gene and siRNA delivery. Int J Pharm 427: 21-34.

32. Shmueli RB, Sunshine JC, Xu Z, Duh EJ, Green JJ (2012) Gene delivery nanoparticles specific for human microvasculature and macrovasculature. Nanomedicine Nanotechnol. Biol. Med 8: 1200-1207.

33. Shim MS, Kwon YJ (2012) Stimuli-responsive polymers and nanomaterials for gene delivery and imaging applications. Adv Drug Deliv Rev 64: 1046-1059.

34. Shan Y, Luo T, Peng C, Sheng R, Cao A, et al. (2012) Gene delivery using dendrimer-entrapped gold nanoparticles as nonviral vectors. Biomaterials 33 : 3025-3035.

35. Mannel H, Pircher J, Fochler F, Stampnik Y, Räthel T, et al. (2012) Site directed 
Citation: Massadeh S, Al-Aamery M, Bawazeer S, AlAhmad O, AlSubai R, et al. (2016) Nano-materials for Gene Therapy: An Efficient Way in Overcoming Challenges of Gene Delivery. J Biosens Bioelectron 7: 195. doi:10.4172/2155-6210.1000195

vascular gene delivery in vivo by ultrasonic destruction of magnetic nanoparticle coated microbubbles. Nanomedicine 8: 1309-1318.

36. Liang Y, Liu Z, Shuai X, Wang W, Liu J, et al. (2012) Delivery of cationic polymer-siRNA nanoparticles for gene therapies in neural regeneration. Biochem Biophys Res Commun 421: 690-695.

37. Haque F, Shu D, Shu Y, Shlyakhtenko LS, Rychahou PG, et al. (2012) Ultrastable synergistic tetravalent RNA nanoparticles for targeting to cancers. Nano Today 7: 245-257.

38. Ai J, Xu Y, Lou B, Li D, Wang E (2014) Multifunctional AS1411-functionalized fluorescent gold nanoparticles for targeted cancer cell imaging and efficient photodynamic therapy. Talanta 118: 54-60.

39. Tang Y, Han S, Liu H, Chen X, Huang L, et al. (2013) The role of surface chemistry in determining in vivo biodistribution and toxicity of CdSe/ZnS coreshell quantum dots. Biomaterials 34: 8741-8755

40. Lu Y, Su Y, Zhou Y, Wang J, Peng F, et al. (2013) In vivo behavior of near infrared-emitting quantum dots. Biomaterials 34: 4302-4308.

41. Ding Y, Zhou YY, Chen H, Geng DD, Wu DY, et al. (2013) The performance of thiol-terminated PEG-paclitaxel-conjugated gold nanoparticles. Biomaterials 34: 10217-10227.

42. Blankenstein T, Leisegang M, Uckert W, Schreiber H (2015) Targeting cancerspecific mutations by $\mathrm{T}$ cell receptor gene therapy. Curr Opin Immunol 33: $112-119$.

43. Aoyama Y, Kobayashi K, Morishita Y, Maeda K, Murohara T (2015) Wnt11 gene therapy with adeno-associated virus 9 improves the survival of mice with myocarditis induced by coxsackievirus B3 through the suppression of the inflammatory reaction. J Mol Cell Cardiol 84: 45-51.

44. Ashcroft RE (2004) Gene therapy in the clinic: whose risks? Trends Biotechno 22: $560-563$

45. Chinen J, Puck JM (2004) Successes and risks of gene therapy in primary immunodeficiencies. J Allergy Clin Immunol 113: 595-603.

46. Wagner AM, Schoeberlein A, Surbek D (2009) Fetal gene therapy: opportunities and risks. Adv Drug Deliv Rev 61: 813-821.

47. Hackett PB, Largaespada DA, Switzer KC, Cooper LJ (2013) Evaluating risks of insertional mutagenesis by DNA transposons in gene therapy. Transl Res 161: $265-283$.

48. Kamei K, Mukai Y, Kojima H, Yoshikawa T, Yoshikawa M, et al. (2009) Direct cell entry of gold/iron-oxide magnetic nanoparticles in adenovirus mediated gene delivery. Biomaterials 30: 1809-1814.

49. Barnhill HN, Reuther R, Ferguson PL, Dreher T, Wang Q (2007) Turnip yellow mosaic virus as a chemoaddressable bionanoparticle. Bioconjug Chem 18: 852-859.

50. Schiøtz BL, Roos N, Rishovd AL, Gjøen T (2010) Formation of autophagosomes and redistribution of LC3 upon in vitro infection with infectious salmon anemia virus. Virus Res 151: 104-107.

51. Rocha CS, Wiklander OP, Larsson L, Moreno PM, Parini P, et al. (2015) RNA therapeutics inactivate PCSK9 by inducing a unique intracellular retention form. J Mol Cell Cardiol 82: 186-193.

52. Chen $Y$, Gao DY, Huang $L$ (2015) In vivo delivery of miRNAs for cancer therapy: challenges and strategies. Adv Drug Deliv Rev 81: 128-141.

53. Zhu XH, Liao B, Liu K, Liu YH (2014) Effect of RNA interference therapy on the mice eosinophils CCR3 gene and granule protein in the murine model of allergic rhinitis. Asian Pac J Trop Med 7: 226-230.

54. Yan F, Fu Q (2014) PLCîn1: a potential target of RNA interference therapy for gastric cancer. Biochem Biophys Res Commun 448: 409-413.

55. Takahashi H, Carninci $P$ (2014) Widespread genome transcription: new possibilities for RNA therapies. Biochem Biophys Res Commun 452: 294-301.

56. Deng Y, Wang CC, Choy KW, Du Q, Chen J, et al. (2014) Therapeutic potentials of gene silencing by RNA interference: principles, challenges, and new strategies. Gene 538: 217-227.

57. Lei C, Cui Y, Zheng L, Chow PK, Wang CH (2013) Development of a gene/ drug dual delivery system for brain tumor therapy: potent inhibition via RNA interference and synergistic effects. Biomaterials 34: 7483-7494.
58. Kim JE, Hwang MH, Lee HW, Lee SW, Lee J, et al. (2013) Combined RNA interference of adenine nucleotide translocase-2 and ganciclovir therapy in hepatocellular carcinoma. Nucl Med Biol 40: 987-993.

59. Intini G (2010) Future approaches in periodontal regeneration: gene therapy, stem cells, and RNA interference. Dent Clin North Am 54: 141-155.

60. Takahashi Y, Nishikawa M, Takakura Y (2009) Nonviral vector-mediated RNA interference: its gene silencing characteristics and important factors to achieve RNAi-based gene therapy. Adv Drug Deliv Rev 61: 760-766.

61. Boado RJ (2005) RNA interference and nonviral targeted gene therapy of experimental brain cancer. NeuroRx 2: 139-150.

62. Michienzi A (2003) Novel ribozyme, RNA decoy, and siRNA approaches to inhibition of HIV in a gene therapy setting. Clin Appl Immunol Rev 223-233.

63. Watanabe T, Sullenger BA (2000) RNA repair: a novel approach to gene therapy. Adv Drug Deliv Rev 44: 109-118.

64. Zamore PD, Tuschl T, Sharp PA, Bartel DP (2000) RNAi: double-stranded RNA directs the ATP-dependent cleavage of mRNA at 21 to 23 nucleotide intervals. Cell 101: 25-33.

65. Hammond SM, Bernstein E, Beach D, Hannon GJ (2000) An RNA-directed nuclease mediates post-transcriptional gene silencing in Drosophila cells. Nature 404: 293-296

66. Hamilton AJ, Baulcombe DC (1999) A species of small antisense RNA in posttranscriptional gene silencing in plants. Science 286: 950-952.

67. Elbashir SM, Harborth J, Lendeckel W, Yalcin A, Weber K, et al. (2001) Duplexes of 21-nucleotide RNAs mediate RNA interference in cultured mammalian cells. Nature 411: 494-498.

68. Elbashir SM, Lendeckel W, Tuschl T (2001) RNA interference is mediated by 21- and 22-nucleotide RNAs. Genes Dev 15: 188-200.

69. Behlke MA (2006) Progress towards in vivo use of siRNAs. Mol Ther 13: 644 670

70. Guo P, Coban O, Snead NM, Trebley J, Hoeprich S, et al. (2010) Engineering RNA for targeted siRNA delivery and medical application. Adv Drug Deliv Rev 62: $650-666$.

71. Birmingham A, Anderson EM, Reynolds A, Ilsley-Tyree D, Leake D, et al (2006) 3' UTR seed matches, but not overall identity, are associated with RNA off-targets. Nat Methods 3: 199-204.

72. Jackson AL, Bartz SR, Schelter J, Kobayashi SV, Burchard J, et al. (2003) Expression profiling reveals off-target gene regulation by RNAi. Nat Biotechno 21: $635-637$.

73. Reynolds A, Anderson EM, Vermeulen A, Fedorov Y, Robinson K, et al. (2006) Induction of the interferon response by siRNA is cell type- and duplex lengthdependent. RNA 12: 988-993.

74. Hornung V, Guenthner-Biller M, Bourquin C, Ablasser A, Schlee M, et al. (2005) Sequence-specific potent induction of IFN-alpha by short interfering RNA in plasmacytoid dendritic cells through TLR7. Nat Med 11: 263-270.

75. Aagaard L, Rossi JJ (2007) RNAi Therapeutics: Principles, Prospects and Challenges. Adv Drug Deliv Rev 59: 75-86.

76. Gao Y, Liu XL, Li XR (2011) Research progress on siRNA delivery with nonviral carriers. Int J Nanomedicine 6: 1017-1025.

77. Navarro G, Tros de Ilarduya C (2009) Activated and non-activated PAMAM dendrimers for gene delivery in vitro and in vivo. Nanomedicine 5: 287-297.

78. Putnam D, Gentry CA, Pack DW, Langer R (2001) Polymer-based gene delivery with low cytotoxicity by a unique balance of side-chain termini. Proc Natl Acad Sci USA 98: 1200-1205.

79. Choi K, Jang M, Kim J, Ahn HJ (2014) Tumor-specific delivery of siRNA using supramolecular assembly of hyaluronic acid nanoparticles and $2 \mathrm{~b}$ RNA-binding protein/siRNA complexes. Biomaterials 35: 7121-7132.

80. Mohammadi Z (2011) Preparation and evaluation of chitosan DNA-FAP-B nanoparticles as a novel non-viral vector for gene delivery to the lung epithelial cells. Int J Pharm 409: 307-313.

81. Das J, Das S, Paul A, Samadder A, Bhattacharyya SS, et al. (2014) Assessment of drug delivery and anticancer potentials of nanoparticles-loaded SiRNA targeting STAT3 in lung cancer, in vitro and in vivo. Toxicol Lett 225: 454-466. 
Citation: Massadeh S, Al-Aamery M, Bawazeer S, AlAhmad O, AlSubai R, et al. (2016) Nano-materials for Gene Therapy: An Efficient Way in Overcoming Challenges of Gene Delivery. J Biosens Bioelectron 7: 195. doi:10.4172/2155-6210.1000195

82. Ragelle H, Riva R, Vandermeulen G, Naeye B, Pourcelle V, et al. (2014) Chitosan nanoparticles for siRNA delivery: optimizing formulation to increase stability and efficiency. J Control Release 176: 54-63.

83. Malhotra M, Tomaro DC, Prakash S (2013) Synthesis of TAT peptidetagged PEGylated chitosan nanoparticles for siRNA delivery targeting neurodegenerative diseases. Biomaterials 34: 1270-1280.

84. Li T, Yawata SC, Honke K (2014) Efficient siRNA delivery and tumo accumulation mediated by ionically cross-linked folic acid-poly(ethylene glycol)-chitosan oligosaccharide lactate nanoparticles: For the potential targeted ovarian cancer gene therapy. Eur J Pharm Sci 5: 48-61.

85. Xie Y (2014) PEGylated carboxymethyl chitosan/calcium phosphate hybrid anionic nanoparticles mediated hTERT siRNA delivery for anticancer therapy. Biomaterials 35: 7978-7991.

86. Han L, Tang C, Yin C (2014) Oral delivery of shRNA and siRNA via multifunctional polymeric nanoparticles for synergistic cancer therapy. Biomaterials 35: 4589-4600.

87. Vauthier C, Zandanel C, Ramon AL (2013) Chitosan-based nanoparticles for in vivo delivery of interfering agents including siRNA. Curr. Opin. Colloid Interface Sci 18: 406-418

88. Lee JY, Lee SH, Oh MH, Kim JS, Park TG, et al. (2012) Prolonged gene silencing by siRNA/chitosan-g-deoxycholic acid polyplexes loaded within biodegradable polymer nanoparticles. J Control Release 162: 407-413.

89. Bishop CJ, Tzeng SY, Green JJ (2015) Degradable polymer-coated gold nanoparticles for co-delivery of DNA and siRNA. Acta Biomater 11: 393-403.

90. Colombo S, Cun D, Remaut K, Bunker M, Zhang J, et al. (2015) Mechanistic profiling of the siRNA delivery dynamics of lipid-polymer hybrid nanoparticles. J Control Release 201: 22-31.

91. Zhong J (2015) Development of hybrid-type modified chitosan derivative nanoparticles for the intracellular delivery of midkine-siRNA in hepatocellular carcinoma cells. Hepatobiliary Pancreat. Dis. Int 14: 82-89.

92. Zheng W (2015) Multifunctional polyamidoamine-modified selenium nanoparticles dual-delivering siRNA and cisplatin to A549/DDP cells for reversal multidrug resistance. Acta Biomater 1: 368-380.

93. Zhao X, Li F, Li Y, Wang H, Ren H, et al. (2015) Co-delivery of HIF1 $\mathbf{I}$ siRNA and gemcitabine via biocompatible lipid-polymer hybrid nanoparticles for effective treatment of pancreatic cancer. Biomaterials 46: 13-25

94. Yhee JY, Song S, Lee SJ, Park SG, Kim KS, et al. (2015) Cancer-targeted MDR-1 siRNA delivery using self-cross-linked glycol chitosan nanoparticles to overcome drug resistance. J Control Release 198: 1-9.

95. Tang S, Yin Q, Su J, Sun H, Meng Q, et al. (2015) Inhibition of metastasis and growth of breast cancer by $\mathrm{pH}$-sensitive poly ( $\hat{l}^{2}$-amino ester) nanoparticles codelivering two siRNA and paclitaxel. Biomaterials 48: 1-15.

96. Han S, Cheng Q, Wu Y, Zhou J, Long X, et al. (2015) Effects of hydrophobic core components in amphiphilic PDMAEMA nanoparticles on siRNA delivery. Biomaterials 48: 45-55

97. Han J, Cai J, Borjihan W, Ganbold T, Rana TM, et al. (2015) Preparation of novel curdlan nanoparticles for intracellular siRNA delivery. Carbohydr Polym 117: 324-330.

98. Kesharwani P, Jain K, Jain NK (2014) Dendrimer as nanocarrier for drug delivery. Top. Issue Biorelated Polym 39: 268-307.

99. Gillies ER, Fréchet JM (2005) Dendrimers and dendritic polymers in drug delivery. Drug Discov Today 10: 35-43.

100. Tomalia DA, Frechet JM (2002) J. Discovery of dendrimers and dendritic polymers: A brief historical perspective. J Polym Sci Part Polym Chem 40: 2719-2728.

101. Malik A, Chaudhary S, Garg G, Tomar A (2012) Dendrimers: A Tool for Drug Delivery. Adv Biol Res 6: 165-169.

102. Chaplot SP, Rupenthal ID (2014) Dendrimers for gene delivery--a potential approach for ocular therapy? J Pharm Pharmacol 66: 542-556.

103.Boas U, Christensen JB, Heegaard PMH (2006) Dendrimers: Design Synthesis and Chemical Properties. J Mater Chem 16: 3785-3798.

104. Klajnert B, Bryszewska M (2001) Dendrimers: properties and applications. Acta Biochim Pol 48: 199-208.
105. Wiesler UM, Berresheim AJ, Morgenroth F, Lieser G, Müllen K (2001) Divergent Synthesis of Polyphenylene Dendrimers:? The Role of Core and Branching Reagents upon Size and Shape. Macromolecules 34: 187-199.

106. Ihre H, Padilla De Jesús OL, Fréchet JM (2001) Fast and convenient divergent synthesis of aliphatic ester dendrimers by anhydride coupling. J Am Chem Soc 123: 5908-5917.

107. Twibanire JK, Grindley TB (2014) Polyester Dendrimers: Smart Carriers for Drug Delivery. Polyester 6: 179-213.

108. Madaan K, Kumar S, Poonia N, Lather V, Pandita D (2014) Dendrimers in drug delivery and targeting: Drug-dendrimer interactions and toxicity issues. $J$ Pharm Bioallied Sci 6: 139-150.

109. Dufès C, Uchegbu IF, Schätzlein AG (2005) Dendrimers in gene delivery. Adv Drug Deliv Rev 57: 2177-2202.

110. Marvaniya HM, Parikh P, Patel V, Modi K, Jjyoti SD (2010). Dendrimer Nano carriers as Versatile Vectors in Gene Delivery. J Chem Pharm Res 97-108.

111. Svenson S, Tomalia DA (2005) Dendrimers in biomedical applicationsreflections on the field. Adv Drug Deliv Rev 57: 2106-2129.

112. Eliyahu H, Barenholz Y, Domb AJ (2005) Polymers for DNA delivery. Molecules 10: 34-64.

113. Ouyang D, Zhang $\mathrm{H}$, Parekh HS, Smith SC (2011) The effect of pH on PAMAM dendrimer-siRNA complexation-Endosomal considerations as determined by molecular dynamics simulation. Biophys Chem 158: 126-133.

114. Daneshvar N, Abdullah R, Shamsabadi FT, How CW, Mh MA, et al. (2013) PAMAM dendrimer roles in gene delivery methods and stem cell research. Cell Biol Int 37: 415-419.

115. Tang $Y$, Li YB, Wang B, Lin RY, van Dongen M, et al. (2012) Efficient in vitro siRNA delivery and intramuscular gene silencing using PEG-modified PAMAM dendrimers. Mol Pharm 9: 1812-1821.

116. Sun Y, Jiao Y, Wang Y, Lu D, Yang W (2014) The strategy to improve gene transfection efficiency and biocompatibility of hyperbranched PAMAM with the cooperation of PEGylated hyperbranched PAMAM. Int J Pharm 465: 112-119.

117. Shah V, Taratula O, Garbuzenko OB, Patil ML, Savla R, et al. (2013) Genotoxicity of different nanocarriers: possible modifications for the delivery of nucleic acids. Curr Drug Discov Technol 10: 8-15.

118. Zinselmeyer BH, Mackay SP, Schatzlein AG, Uchegbu IF (2002) The lowergeneration polypropylenimine dendrimers are effective gene-transfer agents. Pharm Res 19: 960-967.

119. Schatzlein AG, Zinselmeyer BH, Elouzi A, Dufes C, Chim YT, et al. (2005) Preferential liver gene expression with polypropylenimine dendrimers. J Control Release 101: 247-258

120.Kim TI, Baek JU, Zhe Bai C, Park JS (2007) Arginine-conjugated polypropylenimine dendrimer as a non-toxic and efficient gene delivery carrier. Biomaterials 28: 2061-2067

121. Taratula O, Garbuzenko OB, Kirkpatrick P, Pandya I, Savla R, et al. (2009) Surface-engineered targeted $\mathrm{PPI}$ dendrimer for efficient intracellular and intratumoral siRNA delivery. J Control Release 140: 284-293.

122. Russ V, Günther M, Halama A, Ogris M, Wagner E (2008) Oligoethyleniminegrafted polypropylenimine dendrimers as degradable and biocompatible synthetic vectors for gene delivery. J Control Release 132: 131-140.

123. Intra J, Salem AK (2008) Characterization of the transgene expression generated by branched and linear polyethylenimine-plasmid DNA nanoparticles in vitro and after intraperitoneal injection in vivo. Fifth Int. Nanomedicine Drug Deliv. Symp 130: 129-138.

124.Singha K, Namgung R, Kim WJ (2011) Polymers in small-interfering RNA delivery. Nucleic Acid Ther 21: 133-147.

125. Wada K, Arima H, Tsutsumi T, Chihara Y, Hattori K, et al. (2005) Improvement of gene delivery mediated by mannosylated dendrimer/alpha-cyclodextrin conjugates. J Control Release 104: 397-413.

126. Arima H, Motoyama K, Higashi T (2013) Sugar-appended polyamidoamine dendrimer conjugates with cyclodextrins as cell-specific non-viral vectors. Adv Drug Deliv Rev 65: 1204-1214.

127. Luo K, Li C, Wang G, Nie Y, He B, et al. (2011) Peptide dendrimers as 
Citation: Massadeh S, Al-Aamery M, Bawazeer S, AlAhmad O, AlSubai R, et al. (2016) Nano-materials for Gene Therapy: An Efficient Way in Overcoming Challenges of Gene Delivery. J Biosens Bioelectron 7: 195. doi:10.4172/2155-6210.1000195

Page 12 of 12

efficient and biocompatible gene delivery vectors: Synthesis and in vitro characterization. J Control Release 155: 77-87.

128. Luo K, Li C, Li L, She W, Wang G, et al. (2012) Arginine functionalized peptide dendrimers as potential gene delivery vehicles. Biomaterials 33: 4917-4927.

129. Balazs DA, Godbey W (2011) Liposomes for use in gene delivery. J Drug Deliv 2011: 326497

130. Akbarzadeh A, Rezaei-Sadabady R, Davaran S, Joo SW, Zarghami N, et al. (2013) Liposome: classification, preparation, and applications. Nanoscale Res Lett 8: 102.

131. Dizaj SM, Jafari S, Khosroushahi AY (2014) A sight on the current nanoparticlebased gene delivery vectors. Nanoscale Res Lett 9: 252

132. Shim G, Kim MG, Park JY, Oh YK (2013) Application of cationic liposomes for delivery of nucleic acids. Spec. Issue Liposomes 8: 72-80.

133. Elouahabi A, Ruysschaert JM (2005) Formation and intracellular trafficking of lipoplexes and polyplexes. Mol Ther 11: 336-347.

134. Martin B, Sainlos M, Aissaoui A, Oudrhiri N, Hauchecorne M, et al. (2005) The design of cationic lipids for gene delivery. Curr Pharm Des 11: 375-394.

135. Karmali PP, Chaudhuri A (2007) Cationic liposomes as non-viral carriers of gene medicines: resolved issues, open questions, and future promises. Med Res Rev 27: 696-722.

136. Mével M, Kamaly N, Carmona S, Oliver MH, Jorgensen MR, et al. (2010) DODAG; a versatile new cationic lipid that mediates efficient delivery of pDNA and siRNA. J Control Release 143: 222-232.

137. Kawaura C, Noguchi A, Furuno T, Nakanishi M (1998) Atomic force microscopy for studying gene transfection mediated by cationic liposomes with a cationic cholesterol derivative. FEBS Lett 4: 69-72 (1998).

138. Lin Q, Chen J, Zhang Z, Zheng G (2014) Lipid-based nanoparticles in the systemic delivery of siRNA. Nanomedicine (Lond) 9: 105-120.

139.Sonoke S, Ueda T, Fujiwara K, Sato Y, Takagaki K, et al. (2008) Tumor regression in mice by delivery of $\mathrm{Bcl}-2$ small interfering RNA with pegylated cationic liposomes. Cancer Res 68: 8843-8851.

140. Buyens K, De Smedt SC, Braeckmans K, Demeester J, Peeters L, et al. (2012) Liposome based systems for systemic siRNA delivery: stability in blood sets the requirements for optimal carrier design. J Control Release 158: 362-370.

141. Morishita N, Nakagami H, Morishita R, Takeda S, Mishima F, et al. (2005) Magnetic nanoparticles with surface modification enhanced gene delivery of HVJ-E vector. Biochem Biophys Res Commun 334: 1121-1126.

142. Scherer F, Anton M, Schillinger U, Henke J, Bergemann C, et al. (2002) Magnetofection: enhancing and targeting gene delivery by magnetic force in vitro and in vivo. Gene Ther 9: 102-109.

143. Neuberger T, Schopf B, Hofmann H, Hofmann M, Rechenberg B (2005) Superparamagnetic nanoparticles for biomedical applications: Possibilities and limitations of a new drug delivery system. J Magn Magn Mater 29: 483496.

144.von Harpe A, Petersen H, Li Y, Kissel T (2000) Characterization of commercially available and synthesized polyethylenimines for gene delivery. $J$
Control Release 69: 309-322.

145. Godbey WT, Wu KK, Mikos AG (1999) Poly(ethylenimine) and its role in gene delivery. J Control Release 60: 149-160.

146. Huth S, Lausier J, Gersting SW, Rudolph C, Plank C, et al. (2004) Insights into the mechanism of magnetofection using PEl-based magnetofectins for gene transfer. J Gene Med 6: 923-936.

147. Duncan B, Kim C, Rotello VM (2010) Gold nanoparticle platforms as drug and biomacromolecule delivery systems. J Control Release 148: 122-127.

148. Boisselier E, Astruc D (2009) Gold nanoparticles in nanomedicine: preparations, imaging, diagnostics, therapies and toxicity. Chem Soc Rev 38: 1759-1782.

149. Li D (2007) Thermosensitive Nanostructures Comprising Gold Nanoparticles Grafted with Block Copolymers. Adv Funct Mater 17: 3134-3140.

150. Li D, Li G, Guo W, Li P, Wang E, et al. (2008) Glutathione-mediated release of functional plasmid DNA from positively charged quantum dots. Biomaterials 29: 2776-2782

151. Ghosh PS, Kim CK, Han G, Forbes NS, Rotello VM (2008) Efficient gene delivery vectors by tuning the surface charge density of amino acidfunctionalized gold nanoparticles. ACS Nano 2: 2213-2218.

152. Ghosh R, Singh LC, Shohet JM, Gunaratne PH (2013) A gold nanoparticle platform for the delivery of functional microRNAs into cancer cells. Biomaterials 34: 807-816.

153. Sharma A, Tandon A, Tovey JC, Gupta R, Robertson JD, et al. (2011) Polyethylenimine-conjugated gold nanoparticles: Gene transfer potential and low toxicity in the cornea. Nanomedicine 7: 505-513.

154. Balakirev M, Schoehn G, Chroboczek J (2000) Lipoic acid-derived amphiphiles for redox-controlled DNA delivery. Chem Biol 7: 813-819.

155. Tandon A, Sharma A, Rodier JT, Klibanov AM, Rieger FG, et al. (2013) BMP7 gene transfer via gold nanoparticles into stroma inhibits corneal fibrosis in vivo. PLoS One 8: e66434.

156. Ryou SM, Kim JM, Yeom JH, Hyun S, Kim S, et al. (2011) Gold nanoparticleassisted delivery of small, highly structured RNA into the nuclei of human cells. Biochem Biophys Res Commun 416: 178-183.

157. Carlisle RC, Etrych T, Briggs SS, Preece JA, Ulbrich K, et al. (2004) Polymercoated polyethylenimine/DNA complexes designed for triggered activation by intracellular reduction. J Gene Med 6: 337-344.

158. Chen AA, Derfus AM, Khetani SR, Bhatia SN (2005) Quantum dots to monitor RNAi delivery and improve gene silencing. Nucleic Acids Res 33: e190.

159. Klein S, Zolk O, Fromm MF, Schrödl F, Neuhuber W, et al. (2009) Functionalized silicon quantum dots tailored for targeted siRNA delivery. Biochem Biophys Res Commun 387: 164-168.

160.Tan WB, Jiang S, Zhang Y (2007) Quantum-dot based nanoparticles for targeted silencing of HER2/neu gene via RNA interference. Biomaterials 28 : $1565-1571$.

161.Li JM, Zhao MX, Su H, Wang YY, Tan CP, et al. (2011) Multifunctional quantum-dot-based siRNA delivery for HPV18 E6 gene silence and intracellular imaging. Biomaterials 32: 7978-7987. 